\title{
Seasonal acclimatization of eelgrass Zostera marina growth to light
}

\author{
Birgit Olesen, Kaj Sand-Jensen * \\ Biological Institute, Department of Plant Ecology, University ố Aarhus, Nordlandsvej 68, DK-8240 Risskov, Denmark
}

\begin{abstract}
Eelgrass Zostera marina L. was collected in March $\left(7^{\circ} \mathrm{C}\right)$, August $\left(21^{\circ} \mathrm{C}\right)$ and October $\left(15^{\circ} \mathrm{C}\right)$ in a Danish embayment. Growth and acclimatization of the plants were measured in the laboratory at ambient temperature and different photon flux density. Weight loss in the dark increased with temperature whereas the slope of growth versus low light intensities was highest at $15^{\circ} \mathrm{C}$. The light compensation point for zero growth was, therefore, lower $\left(18.5 \mu \mathrm{mol} \mathrm{m} \mathrm{m}^{-2} \mathrm{~s}^{-1}\right)$ for October plants than for March $\left(28.3 \mu \mathrm{mol} \mathrm{m} \mathrm{m}^{-2} \mathrm{~s}^{-1}\right)$ and August $\left(47.3 \mu \mathrm{mol} \mathrm{m} \mathrm{m}^{-2} \mathrm{~s}^{-1}\right)$ plants. Biomass allocation from rhizomes to leaves increased with reduced light availability and rhizomes required more light than leaves to maintain the biomass. Leaf weight normalized to area declined at low light, which together with allocation from rhizomes caused sustained leaf elongation for several weeks, despite severe shading and loss of plant weight. Hence, common determinations of leaf tumover of seagrasses by tagging techniques will always remain positive and cannot be applied to determine the growth energetics at low light under non-steady-state conditions. The experimental light demands for zero growth for March and October plants were equivalent to $11 \%$ of in situ surface irradiance, which is close to estimated light levels at eelgrass depth limits. Eelgrass biomass, however, is expected to increase at the depth limit during summer and to be expended for survival at low light during winter.
\end{abstract}

\section{INTRODUCTION}

Temperate seagrass populations experience marked biomass seasonality due to changing environmental conditions (Duarte 1989). Seasonal growth patterns of eelgrass Zostera marina L. are usually closely related to surface irradiance (Sand-Jensen 1975, Jacobs 1979, Wium-Andersen \& Borum 1984) and maximum depth penetration of seagrasses is set by light availability and shows close correlation to water transparency (Borum 1983, Dennison 1987, Nielsen et al. 1989, Duarte 1991). Minimum light requirements for growth are, therefore, important for regulating production and distribution of seagrass populations. Temperature may modify the response of plants to reduced light availability, because light-limited photosynthesis is believed to be temperature insensitive, whereas respiration increases, thereby resulting in increasing light compensation points for photosynthesis with increasing temperature

\footnotetext{
- Present address: Freshwater Biological Laboratory, University of Copenhagen, Helsingørsgade 51, DK-3400 Hillerød, Denmark
}

(Marsh et al. 1986, Bulthuis 1987). Growth, however, involves many temperature sensitive enzymatic processes so that low temperature may retard growth and increase light compensation points leading to wide differences in light-growth and light-photosynthesis relationships. It is questionable, therefore, to use shortterm photosynthesis-light experiments to estimate light-growth relationships and depth penetration, particularly when plants are not pre-acclimated to experimental conditions (Zimmerman et al. 1989).

Survival and depth penetration of perennial seagrass populations are defined by a year-round integration of factors influencing growth and loss processes. Low light and temperature characterize the winter period as particularly unsuitable for eelgrass growth in Danish waters. Yet, eelgrass plants are able to maintain low leaf growth during winter (McRoy 1969, Wium-Andersen \& Borum 1984) and to keep photosynthetically active leaves (Evans et al. 1986). Carbon reserves of perennial macrophytes assist winter survival and regrowth as light availability increases in spring (Chapman \& Craigie 1978, Dunton 1990, Madsen 1991). Accordingly, summer growth may be essential 
in providing sufficient energy storage for winter survival.

We examine here the coupled influence of seasonal changes in light and temperature on eelgrass growth. We grew plants collected in March, August and October from a Danish embayment, at ambient temperatures and different photon flux density in the laboratory, to determine seasonal variability in the minimum light requirements for growth and biomass allocation patterns of entire eelgrass plants. Shade tolerance and acclimatization of eelgrass plants were described through light-related morphological and physiological changes conducive to maximal growth capacity. We discuss the experimentally derived light compensation points for eelgrass growth with light availability at the eelgrass depth limit in nature, acknowledging the extensive daily and seasonal variability of in situ photon flux density.

\section{METHODS}

Intact eelgrass plants were collected from the same population in Aarhus Bight, Denmark (salinity $20 \%$ ), in March (mean in situ temperature $7^{\circ} \mathrm{C}$ ), August $\left(21^{\circ} \mathrm{C}\right)$ and October $\left(15^{\circ} \mathrm{C}\right)$ and kept for up to $5 \mathrm{~d}$ at low light (ca $30 \mu \mathrm{mol} \mathrm{m} \mathrm{m}^{-2} \mathrm{~s}^{-1}$ ) and ambient temperatures before the growth experiments. In situ daily surface irradiance, calculated from continuous measurements of surface photon flux density over 5 yr (Hydrotechnical Laboratory, Royal Veterinary and Agricultural University) are $14.4 \mathrm{~mol} \mathrm{~m} \mathrm{~m}^{-2} \mathrm{~d}^{-1}$ in March, $35.4 \mathrm{~mol}$ $\mathrm{m}^{-2} \mathrm{~d}^{-1}$ in August and $9.6 \mathrm{~mol} \mathrm{~m} \mathrm{~m}^{-2} \mathrm{~d}^{-1}$ in October. Experimental plants, bearing 5 rhizome segments and associated roots, were blotted with water-absorbing paper and weighed. Length and width of the leaves were measured and the leaves were perforated with a thin needle just above the leaf sheath (viz. SandJensen 1975, Perez et al. 1991) to allow measurements of leaf elongation rates and formation and mortality of leaves.

Individual experimental plants were planted in plastic pots $(4 \times 6 \times 6 \mathrm{~cm})$ containing natural sediment enriched with a stick of slow-release fertilizer (Jobe's; $0.13 \mathrm{~g} \mathrm{~N}, 0.04 \mathrm{~g} \mathrm{P}, 0.03 \mathrm{~g} \mathrm{~K}$ per stick) previously used successfully for growing submerged plants (SandJensen \& Madsen 1991). We enriched the sediments to saturate eelgrass growth so that time of year, temperature and light alone should influence growth performance. Six marked plants were placed in each aquarium. The aquaria were made of black Perspex to prevent light reflection from the sides and contained 20 l of filtered seawater. The water was circulated (2 1 $\mathrm{min}^{-1}$, mean flow velocity $4.5 \mathrm{~cm} \mathrm{~min}^{-1}$ ) between the aquaria and a 50 I reservoir where the water was con- stantly aerated to maintain $\mathrm{O}_{2}$ and $\mathrm{CO}_{2}$ equilibrium with atmospheric air and a constant $\mathrm{pH}$ of 8.2. The water was renewed twice a week. The aquaria were illuminated from above by fluorescent light tubes at 6 different photon flux densities $\left(0\right.$ to $150 \mu \mathrm{mol} \mathrm{m} \mathrm{m}^{-2} \mathrm{~s}^{-1}$ at 7 and $15^{\circ} \mathrm{C}$, and 0 to $300 \mu \mathrm{mol} \mathrm{m} \mathrm{m}^{-2} \mathrm{~s}^{-1}$ at $21^{\circ} \mathrm{C}$ ) measured at mid-depths of the aquaria, when filled with water only, and kept in a $16 \mathrm{~h}$ light $/ 8 \mathrm{~h}$ dark cycle. The higher maximum light intensity at $21^{\circ} \mathrm{C}$ was applied to satisfy the expected higher light requirements. Neutral density plastic filters were used to obtain the desired photon flux density. Plant density was kept low in the aquaria (ca 150 plants $\mathrm{m}^{-2}$ of bottom) relative to common field densities $\left(600\right.$ to $2900 \mathrm{~m}^{-2}$; Sand-Jensen 1975. Wium-Andersen \& Borum 1984) to minimize selfshading. Maximum irradiance experienced at the depth limit of eelgrass in situ is about $100 \mu \mathrm{mol} \mathrm{m} \mathrm{m}^{-2} \mathrm{~s}^{-1}$ at noon during summer provided that about $11 \%$ of subsurface irradiance is available (Duarte 1991).

The plants were grown for 20 to $28 \mathrm{~d}$. Leaf elongation was measured every 3 to $7 \mathrm{~d}$ as the displacement of the punched hole relative to the reference hole on the oldest leaf (no elongation) and the appearance of new leaves and loss of old leaves were noted. Old leaves were harvested before they were shed and analyzed for dry weight and organic dry weight. If old leaves had already lost weight by reallocation or exudation this procedure may underestimate leaf production, but leaves were weighed before they showed visible signs of senescence to minimize this effect. The leaf elongation rate was calculated from measurements during the last 8 to $14 \mathrm{~d}$ when the plants should be well-acclimated to experimental conditions. Rates are expressed as leaf increments per day on each shoot relative to total leaf length $\left(\mathrm{mm} \mathrm{m}^{-1} \mathrm{~d}^{-1}\right)$.

All harvested plants were separated into leaves and rhizomes + roots, and analyzed for leaf length and width, rhizome length and segment number, wet weight, dry weight and organic dry weight and leaf chlorophyll content. Likewise, 15 randomly selected plants were sacrificed and analyzed before the experiment was initiated. Dry weight was measured on freeze-dried material. Organic dry weight (loss on ignition at $\left.550^{\circ} \mathrm{C}\right)$ and leaf chlorophyll $a+b(\mathrm{~N}, \mathrm{~N}$-dimethylformamide extraction and spectrophotometric determinations; Inskeep \& Blum 1985) were measured on subsamples.

The specific growth rate $(\mu)$ of entire plants, and of leaves and rhizomes in separate, were calculated as

$$
\mu=\left(\ln B_{l}-\ln B_{0}\right) t^{-1}
$$

where $B_{0}$ is the initial biomass and $B_{t}$ the final biomass (including the biomass of lost plant parts) after $t \mathrm{~d}$ of incubation. Biomass was calculated as organic dry weight because this is closely related to carbon and en- 
ergy content (Sand-Jensen \& Madsen 1991). The unit of specific growth rate is $\mathrm{g} \mathrm{g}^{-1} \mathrm{~d}^{-1}$ and to achieve properly sized units, it is presented here as $\mathrm{mg} \mathrm{g}^{-1} \mathrm{~d}^{-1}$ (ca $10^{-3} \mathrm{~d}^{-1}$ ). The initial leaf biomass of the experimental plants was determined from measured leaf areas, based on regression of leaf area on leaf fresh weight for the 15 sacrificed plants. The initial rhizome biomass of each plant was calculated from the initially measured shoot fresh weight minus the estimated leaf weight of the plants. These biomass values were then converted to dry weight and organic dry weight from established relationships based on analyses of the 15 shoots.

The relationship between the specific growth rate $(\mu)$ and photon flux density (I) was described by the equation

$$
\mu=\frac{\mu_{\max } \alpha l}{\mu_{\max }+\alpha l}-r_{0}
$$

where $\alpha$ represents the efficiency of light utilization for growth at low light (the initial linear slope of $\mu$ versus $S I), \mu_{\max }$ is the maximum growth rate approached asymptotically at high light and $r_{0}$ is the rate of weight loss in the dark (Baly 1935). The parameters were estimated by nonlinear regression. The light compensation point for growth $\left(I_{C}\right)$ was estimated as

$$
I_{\mathrm{c}}=\frac{\mu_{\max } \Gamma_{0}}{\alpha \mu_{\max }-r_{0}}
$$

\section{RESULTS}

\section{Eelgrass growth rates}

Relationships between eelgrass specific growth rate and incident light for plants collected in March $\left(7^{\circ} \mathrm{C}\right)$,

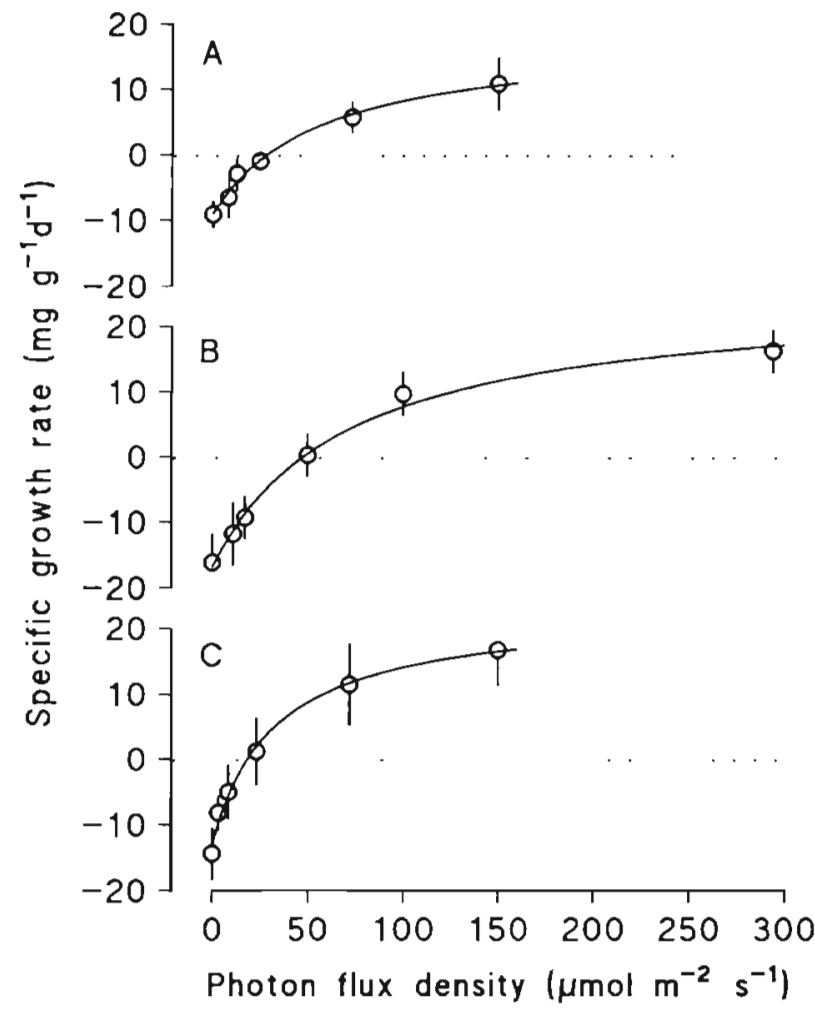

Fig. 1 Zostera marina. Specific growth rates as a function of photon flux density for plants collected in (A) March $\left(7^{\circ} \mathrm{C}\right)$, (B) August $\left(21^{\circ} \mathrm{C}\right)$ and $(\mathrm{C})$ October $\left(15^{\circ} \mathrm{C}\right)$. Symbols represent mean growth rates $( \pm 95 \% \mathrm{CL}, \mathrm{n}=6)$. The curve was fitted by non-linear regression using Eq. 2

August $\left(21^{\circ} \mathrm{C}\right)$ and October $\left(15^{\circ} \mathrm{C}\right)$ reveal an asymptotic relationship between growth rates and photon flux density (Fig. 1). Maximum growth rates at 150 $\mu \mathrm{mol} \mathrm{m} \mathrm{m}^{-2} \mathrm{~s}^{-1}$ were faster in October plants $(16.7 \mathrm{mg}$ $\left.\mathrm{g}^{-1} \mathrm{~d}^{-1}\right)$ than March plants $\left(10.8 \mathrm{mg} \mathrm{g}^{-1} \mathrm{~d}^{-1}\right)$ and were also low $\left(9.7\right.$ and $16.3 \mathrm{mg} \mathrm{g}^{-1} \mathrm{~d}^{-1}$ at 100 and $300 \mu \mathrm{mol}$

Table 1. Zostera marina. Parameters describing eelgrass growth versus light intensity according to Eq. 2 for plants collected in

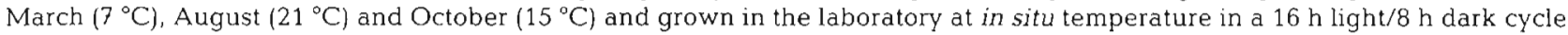
Mean values $\pm \mathrm{SE}$ of $\mu_{\max }$ : maximum specific growth rate $r_{0}$ : specific biomass loss rate in the dark; $\alpha$ : specific growth rate versus

\begin{tabular}{|c|c|c|c|c|c|c|c|c|}
\hline Temp. & & $\left.\underset{\left(m g g^{-1}\right.}{\mu_{\max }} \mathrm{d}^{-1}\right)$ & $\left(\mathrm{mg} \mathrm{g}^{-1} \mathrm{~d}^{-1}\right)$ & $\begin{array}{c}\alpha \\
\left(\mathrm{mg} \mathrm{g}^{-1} \mathrm{~d}^{-1} /\right. \\
\left.\mu \mathrm{mol} \mathrm{m} \mathrm{m}^{-2} \mathrm{~s}^{-1}\right)\end{array}$ & $\left(\mu \mathrm{mol} \mathrm{m} \mathrm{s}^{-2} \mathrm{~s}^{-1}\right)^{I_{c}}$ & $\left(\mathrm{~mol} \mathrm{~m} \mathrm{~m}^{-2} \mathrm{~d}^{-1}\right)$ & $r^{2}$ & $\mathrm{n}$ \\
\hline $7^{\circ} \mathrm{C}$ & $\begin{array}{l}\text { Plants } \\
\text { Leaves } \\
\text { Rhizomes }\end{array}$ & $\begin{array}{l}27.0 \pm 2.9 \\
27.3 \pm 3.2 \\
41.1 \pm 89.8\end{array}$ & $\begin{array}{r}-9.1 \pm 1.0 \\
-10.0 \pm 1.4 \\
-6.2 \pm 2.9\end{array}$ & $\begin{array}{l}0.48 \pm 0.13 \\
0.65 \pm 0.22 \\
0.15 \pm 0.19\end{array}$ & $\begin{array}{l}28.3 \\
24.2 \\
47.5\end{array}$ & $\begin{array}{l}1.63 \\
1.39 \\
2.74\end{array}$ & $\begin{array}{l}0.88 \\
0.81 \\
0.26\end{array}$ & $\begin{array}{l}35 \\
34 \\
34\end{array}$ \\
\hline $21^{\circ} \mathrm{C}$ & $\begin{array}{l}\text { Plants } \\
\text { Leaves } \\
\text { Rhizomes }\end{array}$ & $\begin{array}{l}42.0 \pm 2.9 \\
43.1 \pm 3.4 \\
51.7 \pm 18.3\end{array}$ & $\begin{array}{l}-16.8 \pm 1.3 \\
-14.4 \pm 1.7 \\
-24.5 \pm 2.8\end{array}$ & $\begin{array}{l}0.59 \pm 0.11 \\
0.72 \pm 0.17 \\
0.26 \pm 0.14\end{array}$ & $\begin{array}{r}47.3 \\
29.8 \\
176.7\end{array}$ & $\begin{array}{r}2.72 \\
1.72 \\
10.18\end{array}$ & $\begin{array}{l}0.92 \\
0.88 \\
0.63\end{array}$ & $\begin{array}{l}35 \\
35 \\
33\end{array}$ \\
\hline $15^{\circ} \mathrm{C}$ & $\begin{array}{l}\text { Plants } \\
\text { Leaves } \\
\text { Rhizomes }\end{array}$ & $\begin{array}{l}35.9 \pm 3.3 \\
33.2 \pm 3.1 \\
65.0 \pm 27.4\end{array}$ & $\begin{array}{l}-13.0 \pm 1.5 \\
-11.1 \pm 1.8 \\
-27.3 \pm 4.7\end{array}$ & $\begin{array}{l}1.10 \pm 0.32 \\
1.38 \pm 0.46 \\
0.80 \pm 0.56\end{array}$ & $\begin{array}{l}18.5 \\
12.1 \\
59.4\end{array}$ & $\begin{array}{l}1.07 \\
0.70 \\
3.42\end{array}$ & $\begin{array}{l}0.86 \\
0.82 \\
0.55\end{array}$ & $\begin{array}{l}36 \\
36 \\
33\end{array}$ \\
\hline
\end{tabular}
low light intensities; $I_{c}$ : light compensation point for growth; $r^{2}$ : the coefficient of determination; $n$ : number of measurements 


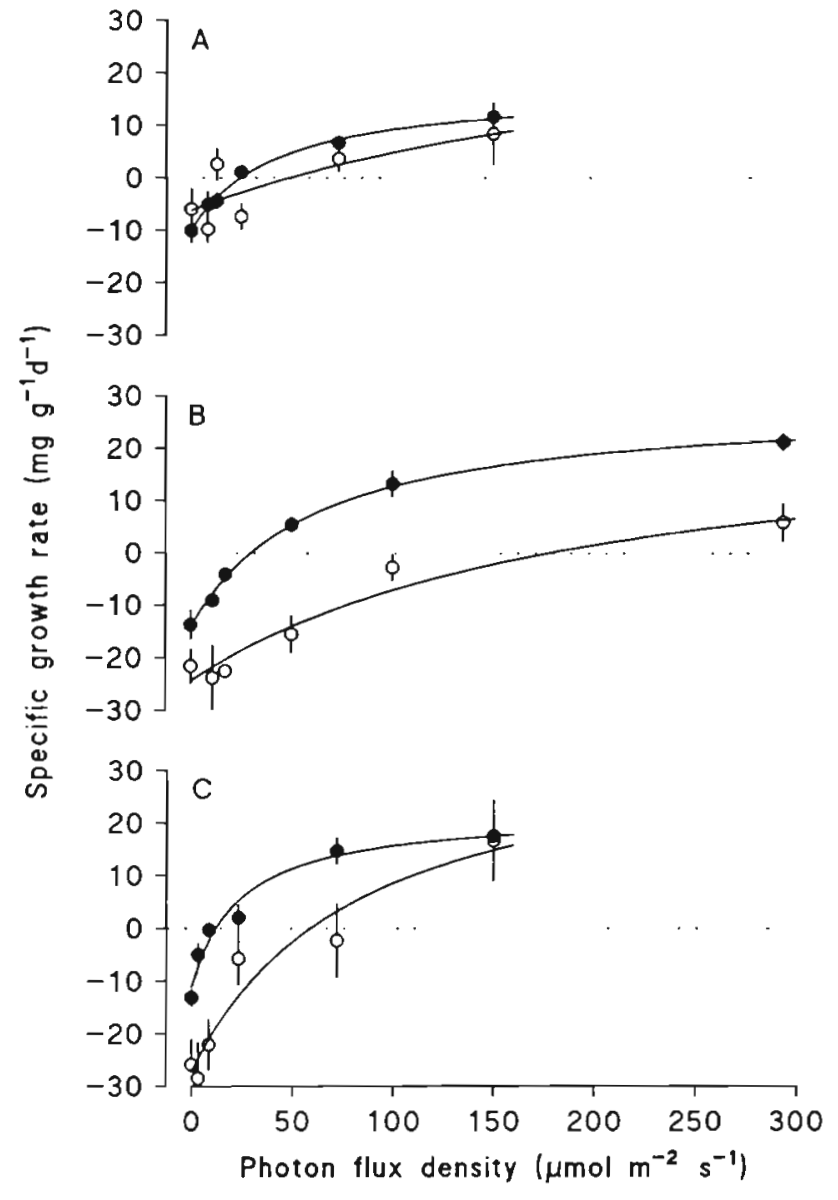

Fig. 2. Zostera marina. Specific growth rates of leaves $(\bullet)$ and rhizomes plus roots (O) as a function of photon flux density for plants collected in (A) March $\left(7^{\circ} \mathrm{C}\right),(\mathrm{B})$ August $\left(21^{\circ} \mathrm{C}\right)$ and $(\mathrm{C})$ October $\left(15^{\circ} \mathrm{C}\right)$. Mean values $( \pm 95 \% \mathrm{CL}, \mathrm{n}=5$ to 6$)$. The curve was fitted by non-linear regression using Eq. 2

$\mathrm{m}^{-2} \mathrm{~s}^{-1}$ ) in August plants (Fig. 1). Growth efficiency at low light $(\alpha)$ was also highest in October plants compared to March and August plants (Table 1). Rate of weight loss in the dark $\left(r_{0}\right)$ increased with ambient temperature from $-9.1 \mathrm{mg} \mathrm{g}^{-1} \mathrm{~d}^{-1}$ at $7^{\circ} \mathrm{C}$ to $-16.8 \mathrm{mg}$ $\mathrm{g}^{-1} \mathrm{~d}^{-1}$ at $21^{\circ} \mathrm{C}$ (Table 1 ), and the light compensation point for growth $\left(I_{c}\right)$ ranged from 18.5 to $47.3 \mu \mathrm{mol} \mathrm{m}{ }^{-2}$ $\mathrm{s}^{-1}$, with the highest values for August plants (Table 1). Thus, despite higher weight loss in the dark of October plants, their greater growth efficiency at low light resulted in a lower light compensation point than found for March plants (Table 1).

Specific growth rate of leaves exceeded that of rhizomes (Fig. 2), apart from March plants, where differences were small. Because leaf growth increased faster with increasing light than rhizome growth, light compensation points were considerably lower for leaves than rhizomes (Table 1). Rhizomes only grew at incident light levels in excess of $50 \mu \mathrm{mol} \mathrm{m} \mathrm{m}^{-2} \mathrm{~s}^{-1}$ for March

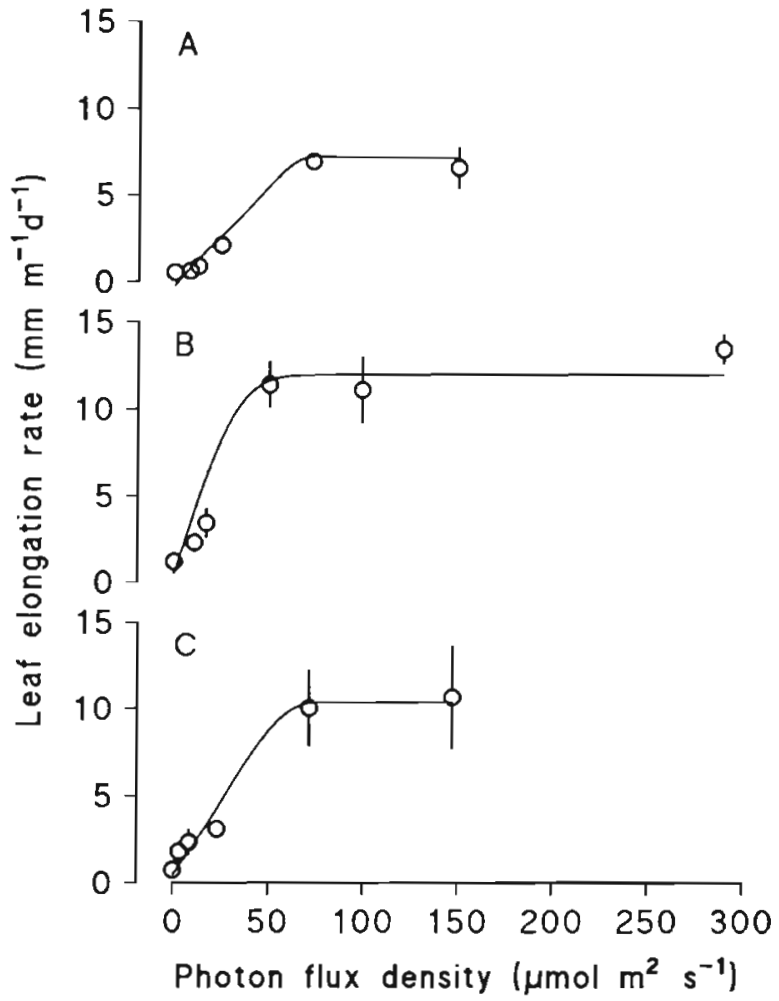

Fig. 3. Zostera marina. Leaf elongation rates as a function of photon flux density of plants collected in (A) March $\left(7^{\circ} \mathrm{C}\right),(\mathrm{B})$ August $\left(21^{\circ} \mathrm{C}\right)$ and $(\mathrm{C})$ October $\left(15^{\circ} \mathrm{C}\right)$. Mean values $( \pm 95 \%$

$C L, n=6$ ). The curve was fitted by eye for contrast only

and October plants, and of $100 \mu \mathrm{mol} \mathrm{m} \mathrm{m}^{-2} \mathrm{~s}^{-1}$ for August plants.

Eelgrass leaves elongated under all light levels (Fig. 3), but elongation gradually ceased in the dark. Maximum leaf elongation rate increased with temperature and varied from $6.6 \mathrm{~mm} \mathrm{~m}^{-1} \mathrm{~d}^{-1}$ at $7^{\circ} \mathrm{C}$ to 13.5

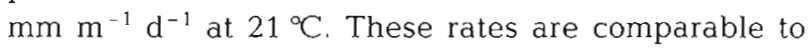
field values measured in eelgrass populations from shallow water in April $\left(4.8 \mathrm{~mm} \mathrm{~m}^{-1} \mathrm{~d}^{-1}\right)$, September (13.7 $\mathrm{mm} \mathrm{m}^{-1} \mathrm{~d}^{-1}$ ) and October $\left(6.3 \mathrm{~mm} \mathrm{~m}^{-1} \mathrm{~d}^{-1}\right.$ ) (Olesen unpubl. data). Leaf elongation rates saturated at lower light levels ( 50 to $70 \mu \mathrm{mol} \mathrm{m} \mathrm{m}^{-2} \mathrm{~s}^{-1}$ ) than the specific growth rate of leaves (Fig. 4), because leaf weight normalized to leaf area (organic content per leaf area) increased with incident light level (see Fig. 6).

\section{Organic dry weight and chlorophyll content}

Specific growth rates of eelgrass plants were calculated based on changes in organic dry weight. The organic proportion of the dry weight was 75 to $80 \%$ and slightly lower at low than higher light (Fig. 5). Thus, the organic content of plants declined faster in low 


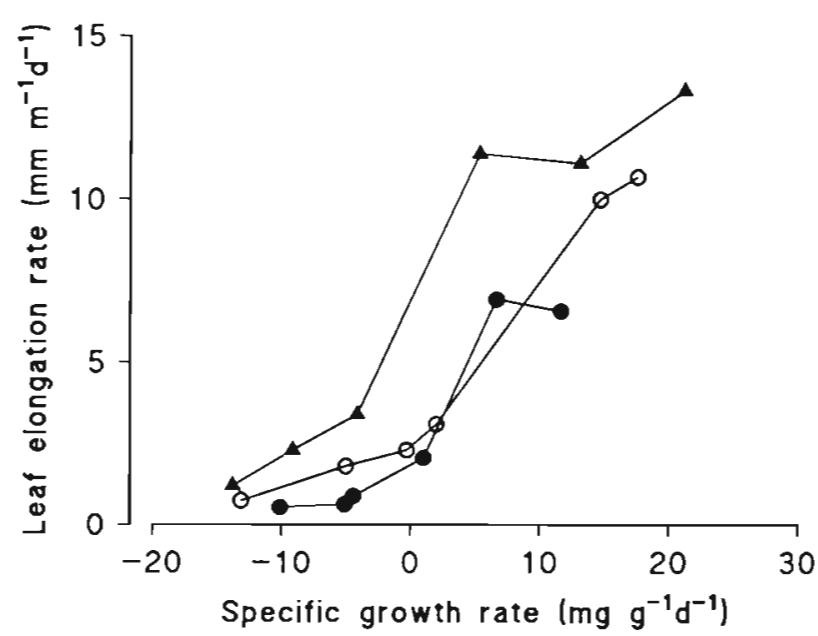

Fig. 4. Zostera marina. Relationship between leaf elongation rates and specific leaf growth rates. Plants were collected in

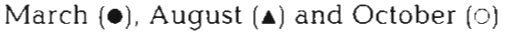

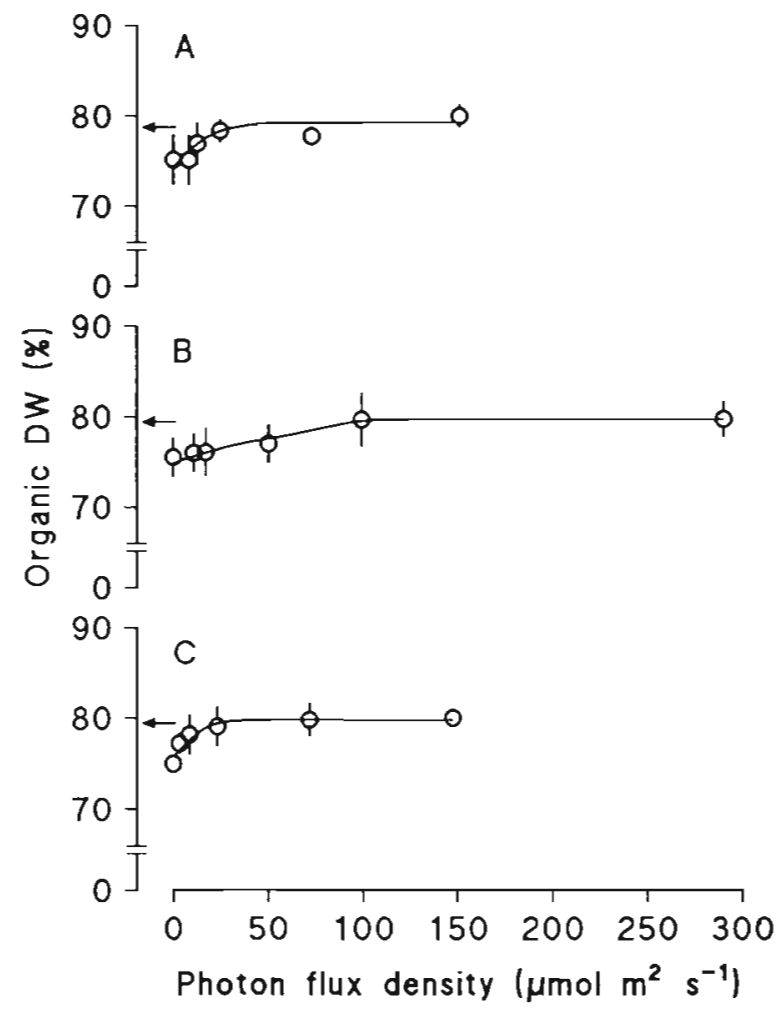

Fig. 5. Zostera marina. Relationship between organic dry weight ( $\%$ of dry weight) and photon flux density for shoots collected in (A) March $\left(7^{\circ} \mathrm{C}\right),(B)$ August $\left(21^{\circ} \mathrm{C}\right)$ and (C) October $\left(15^{\circ} \mathrm{C}\right)$. Mean values $( \pm 95 \% \mathrm{CL}, \mathrm{n}=3$ ). Lines were fitted by eye for contrast only, arrows show initial organic content

light than their dry weight. Leaf weight per unit leaf area also increased with photon flux density but was lower for plants growing at low temperatures $\left(7^{\circ} \mathrm{C}\right)$ (Fig. 6). Chlorophyll content, on a leaf area basis, var-

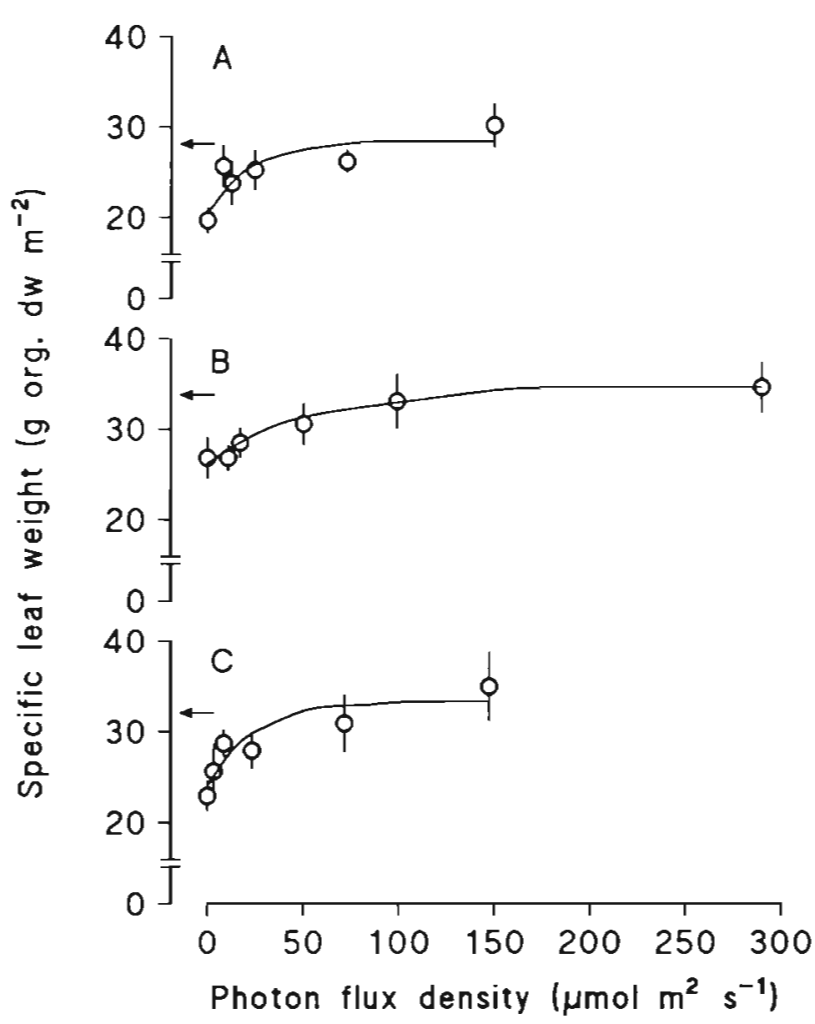

Fig. 6. Zostera marina. Relationship between specific leaf weight and photon flux density for plants collected in (A) March $\left(7^{\circ} \mathrm{C}\right),(\mathrm{B})$ August $\left(21^{\circ} \mathrm{C}\right)$ and $(\mathrm{C})$ October $\left(15^{\circ} \mathrm{C}\right)$ Mean values $( \pm 95 \% \mathrm{CL}, \mathrm{n}=6)$. Lines were fitted by eye for contrast only, arrows show initial organic content

ied with incident photon level (Fig. 7), showing low concentrations in plants exposed to high light and in plants kept in the dark. Chlorophyll content varied more with light intensity for August plants, where leaf turnover was also faster. Maximum chlorophyll concentration achieved at $10 \mu \mathrm{mol} \mathrm{m} \mathrm{m}^{-2} \mathrm{~s}^{-1}$ was more than twice as high as that in the dark for August plants, but only $45 \%$ higher for March and October plants.

\section{DISCUSSION}

\section{Eelgrass growth rates}

Eelgrass growth rates measured as changes in dry weight, organic dry weight and leaf length were differently affected by shading. The organic content constituted a variable proportion of the dry weight depending on photon level and decreased faster than the dry weight in low light (Fig. 5). Calculation of growth rates based on changes in dry weight may therefore overestimate growth at low photon flux densities, because the mineral content is maintained but organic compounds respired. Similar results were found in freshwater mac- 


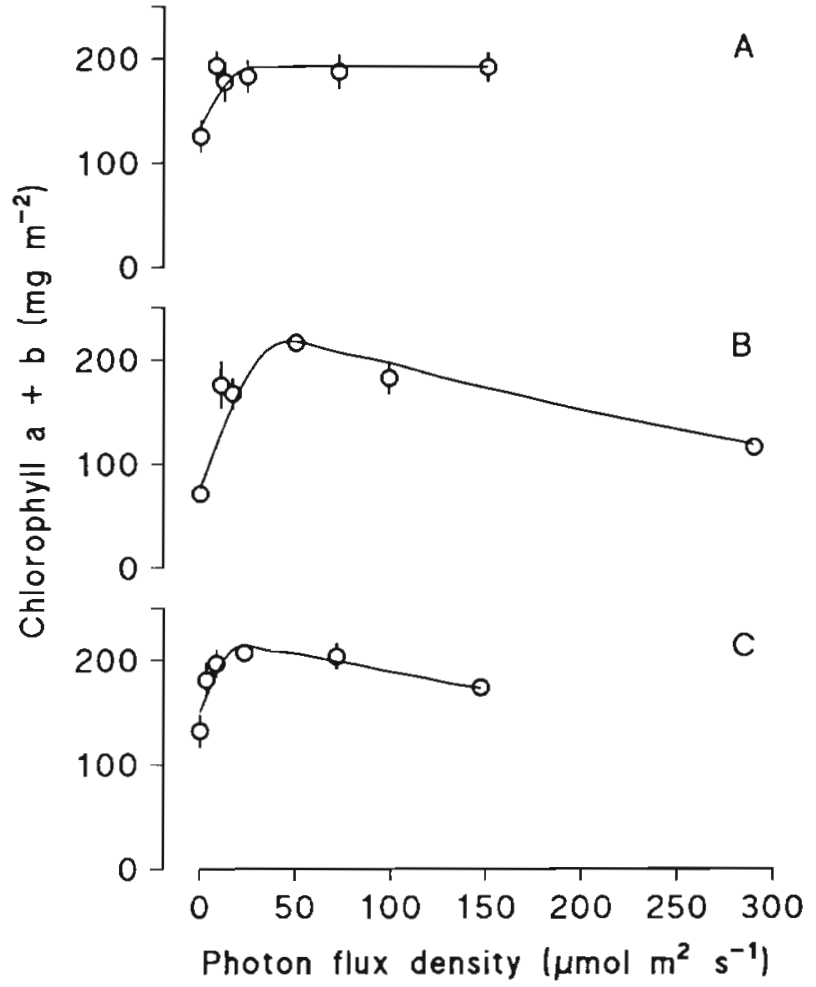

Fig. 7. Zostera marina. Relationships between leaf chlorophyll density and photon flux density for plants collected in (A) March $\left(7^{\circ} \mathrm{C}\right)$, (B) August $\left(21^{\circ} \mathrm{C}\right)$ and (C) October $\left(15^{\circ} \mathrm{C}\right)$. Mean values ( $\pm 95 \% \mathrm{CL}, \mathrm{n}=3$ ). Lines were fitted by eye for contrast only

rophytes (Sand-Jensen \& Madsen 1991) and macroalgae with multi-layered thallus (Markager \& SandJensen unpubl.) and, therefore, seem to be a general phenomenon among aquatic macrophytes. Leaf weight per leaf area also declined with reduced photon flux density, probably because leaves became thinner (Fig. 6). Thus, eelgrass leaves continued to grow in length in low light (Fig. 3) at the expense of reduced leaf size, weight per leaf area, and rhizome biomass, and leaf elongation rate was saturated by light at lower levels than that for leaf biomass (Fig. 4). Similarly, freshwater macrophytes were able to elongate their shoots (Barko et al. 1982) and Ulva lactuca to increase its surface area (Sand-Jensen 1988) at very low light, at the expense of the carbon content. Uncoupling between carbon growth and cell division rates upon changes in light is also known to take place among microalgae (Prézelin \& Sweeney 1978), and diatoms, for example, become smaller following each division (Langdon 1987). Accordingly, comparisons of energy status of plants exposed to varying growth conditions should preferably be based on changes in organic dry weight or carbon content. Seagrass growth under variable field conditions is commonly determined as leaf elongation rates by tagging experiments and subsequently converted to weight units. This procedure will always yield positive values even though individual plant weight and seagrass biomass may decline.

\section{Variation in growth characteristics}

Seasonal changes in light intensity and temperature affected the growth response of eelgrass to reduced light availability (Fig. 1). Outcome of growth experiments is, therefore, influenced by the time of year the experimental plants are collected and particularly so if growth experiments involve short-term acclimation to non-ambient temperatures (Evans et al. 1986, Zimmerman et al. 1989). Rate of weight loss in the dark and estimated maximum growth rate both increased with temperature but the slope $(\alpha)$ of growth versus low light intensities was higher for eelgrass plants acclimated to growth in October compared to those in March and August (Table 1). Light-limited growth is generally considered insensitive to temperature, but growth efficiency of macroalgae, measured in situ (Geertz-Hansen \& Sand-Jensen 1992) or on algae preacclimated to experimental temperatures (Lapointe et al. 1984), often shows a peak at an intermediate temperature within the tolerable physiological temperature range. The growth efficiency for August plants of eelgrass at $21^{\circ} \mathrm{C}$ was also lower, and together with high rates of weight loss in the dark led to high light requirements for growth. This suggests a decline in eelgrass growth at temperatures above $21^{\circ} \mathrm{C}$, perhaps due to higher respiratory maintenance. Similar temperature effects on eelgrass were observed in Chesapeake Bay (USA) through reduced photosynthetic capacity (Evans et al. 1986) and reduced leaf biomass (Orth \& Moore 1986) at temperatures above 19 and $25^{\circ} \mathrm{C}$, respectively.

The biomass allocation pattern of eelgrass was adjusted in response to changing growth conditions, as high temperature and shading caused higher losses of rhizome biomass than leaf biomass (Fig. 2). Thereby, light and temperature affect the proportion of root to leaf biomass in opposing ways (Barko et al. 1982). Energy reserves, whether stored in specialized organs or not, are known to be important for overwintering of submerged macrophytes (Madsen 1991) and macroalgae (Dunton 1990). Eelgrass plants sustained leaf elongation for several weeks at low light though growth eventually stopped in continued darkness (Fig. 3). We have evidence that allocation from rhizomes to leaves of eelgrass occurred at low light because the weight of rhizomes and roots declined 1.6- to 2.1-fold faster than the measured respiration rates of below-ground parts (Olesen unpubl, data). Thus, allo- 
cation from rhizomes and gradually reducing plant weight should be able to support leaf growth during low light winter periods, provided adequate plant growth and storage are achieved during preceding high light periods.

\section{Shade acclimatization}

Submerged macrophytes may acclimate to changing photon flux densities both with season and with depth by more effective light utilization. Reduction of shoot density with declining photon level is a well known response of macrophyte populations to reduce self-shading (Backman \& Barilotti 1976, Barko et al. 1982 Duarte \& Kalff 1987), to prolong the period of active growth in autumn, and to expand the depth limit for growth. Shade acclimatization also includes morphological responses through altered allocation patterns, such as the reduced formation of below-ground biomass with reduced light availability found here and in other laboratory experiments (Barko et al. 1982, SandJensen \& Madsen 1991), or along depth gradients in the field (Chambers \& Kalff 1987, Sondergaard \& Bonde 1988). The observed allocation to leaves, at the expense of rhizomes and roots, tends to maintain growth through increased photosynthetic biomass and reduced respiration of non-photosynthetic tissue (Björkman 1981). Likewise, reduced leaf weight per leaf area (Fig. 6) and increased stem elongation should increase the photosynthetic area without increasing respiratory costs, because leaf mass remains constant or drops (Spence et al. 1973, Björkman 1981). Acclimatization of eelgrass to low light also involved increased chlorophyll concentrations (Fig. 7), though severe shading caused pigmentation loss. Similar patterns have been observed for microalgae (Falkowski et al. 1985), macroalgae (Markager 1993) and terrestrial leaves (Björkman 1981). Areal chlorophyll density of eelgrass leaves was less variable compared to chlorophyll concentrations, normalized to organic dry weight (not shown) because the increasing pigment concentration caused by shading was counteracted by decreasing leaf weight per leaf area. Thereby, photon absorption by leaf chlorophyll remained constant, but reduced weight per leaf area presumably reduced respiration and the cost of leaf synthesis. Eelgrass plants exposed to intermediate photon flux density showed approximately the same areal chlorophyll density (176 to $210 \mathrm{mg}$ Chl $a+b \mathrm{~m}^{-2}$; Fig. 7), which should yield about $75 \%$ absorption of incoming light (FrostChristensen \& Sand-Jensen 1992). The relatively constancy of areal chlorophyll density over a range of light levels suggests that, despite light limitation, further investments in light harvesting capacity through in- creased pigmentation does not confer a significant advantage for light absorption relative to the extra costs of investment. Thus, increased chlorophyll density beyond that necessary to achieve absorption of about $75 \%$ of incoming light will only increase absorption marginally because of minor increase in chlorophyll exposure to incident light (package effect) (FrostChristensen \& Sand-Jensen 1992).

\section{Minimum light requirements for growth}

Light compensation points for growth $\left(I_{c}\right)$ of eelgrass leaves resembled those for photosynthesis of eelgrass (15 to $25 \mu \mathrm{mol} \mathrm{m} \mathrm{m}^{-2} \mathrm{~s}^{-1}$ at $20^{\circ} \mathrm{C}$; Dennison \& Alberte 1985 ) and other seagrass species (9 to $26 \mu \mathrm{mol} \mathrm{m}{ }^{-2} \mathrm{~s}^{-1}$ at 9 to $26{ }^{\circ} \mathrm{C}$; Dennison 1987 ). Higher respiration of entire eelgrass plants, compared to leaves, increased minimum requirements for growth considerably (Table 1). Hence, the ratio between above-and below-ground biomass of seagrasses should be critical to growth in low light environments (Fourqurean \& Zieman 1991). Also, the light requirement of entire eelgrass plants was well above that for freshwater macrophytes with small root development $\left(2.6\right.$ to $11.6 \mu \mathrm{mol} \mathrm{m} \mathrm{m}^{-2} \mathrm{~s}^{-1}$; SandJensen \& Madsen 1991) and for macroalgae (0.3 to $2.5 \mu \mathrm{mol} \mathrm{m} \mathrm{m}^{-2} \mathrm{~s}^{-1}$; Markager \& Sand-Jensen unpubl.), grown under similar experimental conditions $\left(7^{\circ} \mathrm{C}\right)$ as applied in this investigation. Accordingly, more light is probably needed to maintain growth of eelgrass populations, compared to other plant communities with little or no non-photosynthetic tissue, because of high respiratory demands of the rhizome-root biomass.

The lower depth boundary of seagrasses corresponds to an average of approximately $11 \%$ of surface irradiance (Duarte 1991). Experimental light requirements to maintain eelgrass biomass $\left(I_{c}\right)$ measured here ranged from daily integrals of $1.07 \mathrm{~mol} \mathrm{~m} \mathrm{~m}^{-2} \mathrm{~d}^{-1}$ for October plants to $2.72 \mathrm{~mol} \mathrm{~m} \mathrm{~m}^{-2} \mathrm{~d}^{-1}$ for August plants in the $16 \mathrm{~h}$ light/ $8 \mathrm{~h}$ dark cycle applied (Table 1), and were equivalent to $11 \%$ of mean daily surface irradiance in March and October and to $8 \%$ in August. Thus, despite high $I_{C}$-values for August plants, peak irradiance during summer may cause a net increase in biomass for eelgrass populations growing close to the depth limit, as found by Hedal (1992), whereas biomass is expected to decrease during winter, due to the predominance of respiration. Further evaluations of experimental light requirements and light availability at the depth limit cannot be established in this context because of the variability of day length and incident photon flux density in the field involving several nonlinear responses associated, for example, with photosynthetic light utilization.

In summary, seasonal variability in light and ambient 
temperatures affected the growth response of eelgrass to light. Light-saturated growth rates and respiration losses increased with temperature, but October plants, acclimated to growth at $15{ }^{\circ} \mathrm{C}$, showed high efficiency of light utilization and, thereby, lower light compensation points for growth than plants from March $\left(7^{\circ} \mathrm{C}\right)$ and August $\left(21^{\circ} \mathrm{C}\right)$. Eelgrass acclimated to shade by altered biomass allocation, increasing leaf surface area for light absorption and reducing weight proportions and respiration of non-photosynthetic tissue. Thereby, plants maintained leaf elongation at low light intensities, inadequate to support a net gain in plant biomass. Minimum light requirements for March and October plants were equivalent to $11 \%$ of daily surface irradiance, which is close to the mean integral light levels found at eelgrass depth limits. As light availability decreases further during winter, the ability to sustain leaf elongation at low light conditions may be essential for overwintering of eelgrass.

Acknowledgements. This study was supported by the Danish Natural Science Research Council (grant no. 11-7795) and by a grant from the Limfjord Commitee to B.O. We thank Carlos M. Duarte and Stiig Markager for their comments on the manuscript.

\section{LITERATURE CITED}

Backman, T W., Barilotti, D. C. (1976). Irradiance reduction: effects on standing crops of the eelgrass Zostera marina in a coastal lagoon. Mar. Biol. 34: 33-40

Baly, E. C. C. (1935). The kinetics of photosynthesis. Proc. R. Soc. (Ser. B) 117: 218-239

Barko, J. W., Hardin, D. G., Matthews, M. S. (1982). Growth and morphology of submersed freshwater macrophytes in relation to light and temperature. Can. J. Bot. 60: 877-887

Björkman, O. (1981). Responses to different quantum flux densities. In: Lange, O. L., Nobel, P. S., Osmond, C. B., Ziegler, H. (eds.) Encyclopedia of plant physiology, Vol 12A. Physiological plant ecology, I, Responses to the physical environment. Springer-Verlag, Beriin, p. 57-107

Borum, J. (1983). The quantitative role of macrophytes, epiphytes and phytoplankton under different conditions in Roskilde Fjord, Denmark. In: Proc. Int. Symp. Aquatic Macrophytes, Nijmegen, 18-23 September 1983, p. 35-40

Bulthuis, D. S. (1987). Effects of temperature on photosynthesis and growth of seagrasses. Aquat. Bot. 27: 27-40

Chambers, P. A., Kalff, J. (1987). Light and nutrients in the control of aquatic plant community structure. I. In situ experiments. J. Ecol. 75: 61. 1-619

Chapman, A. R. O. Craigie, J. S. (1978). Seasonal growth in Laminaria longicruris: relations with reserve carbohydrate storage and production. Mar. Biol. 46: 209-213

Dennison, W. C. (1987). Effects of light on seagrass photosynthesis, growth and depth distribution. Aquat. Bot. 27: $15-26$

Dennison, W. C., Alberte, R. S. (1985). Role of daily light period in the depth distribution of Zostera marina (eelgrass). Mar. Ecol. Prog. Ser. 25: 51-61

Duarte, C. M. (1989). Temporal biomass varability and production/biomass relationships of seagrass communities. Mar. Ecol. Prog. Ser. 51: 269-276
Duarte, C. M. (1991). Seagrass depth limit. Aquat. Bot. 40: $363-377$

Duarte, C. M., Kalff, J. (1987). Weight-density relationships in submerged macrophytes. The importance of light and plant geometry. Oecologia 72: 612-617

Dunton, K. H. (1990). Growth and production in Laminaria solidungula: relation to continuous underwater light levels in the Alaskan High Arctic. Mar. Biol 106: 297-304

Evans, A. S., Kenneth, L. W., Penhale, P. A. (1986). Photosynthetic temperature acclimation in two coexisting seagrasses, Zostera marina L. and Ruppia maritima L. Aquat. Bot. 24: 185-197

Falkowski, P. G., Dubinsky, Z., Wyman, D. (1985). Growthirradiance relationships in phytoplankton. Limnol. Oceanogr. 30: 311-321

Fourqurean, J. W., Zieman, J. C. (1991). Photosynthesis, respiration and whole plant carbon budget of the seagrass Thalassia testudinum. Mar. Ecol. Prog. Ser. 69: 161-170

Frost-Christensen, H., Sand-Jensen, K. (1992). The quantum efficiency of photosynthesis in macroalgae and submerged angiosperms. Oecologia 91: 377-384

Geertz-Hansen, O., Sand-Jensen, K. (1992). Growth rates and photon yield of growth in natural populations of a marine macroalgae Ulva lactuca. Mar. Ecol. Prog. Ser. 81: $179-183$

Hedal, S. (1992). Bundvegetationen i de indre dele af Roskilde Fjord og Isefjord. Miljokontoret, Roskilde Amt, Roskilde (in Danish)

Inskeep, W. P., Blum, P. R. (1985). Extinction coefficients of chlorophyll $a$ and $b$ in N,N-Dimethylformamid and $80 \%$ acetone. Plant. Physiol. 77: 483-485

Jacobs, R. P. W. M. (1979). Distribution and aspects of the production and biomass of eelgrass, Zostera marina L., at Roscoff, France. Aquat. Bot. 7: 151-172

Langdon, C. (1987). On the causes of interspecific differences in the growth-irradiance relationship for phytoplankton. Part I. A comparative study of the growth-irradiance relationship of three marine phytoplankton species: Skeletonema costatum, Olisthodiscus luteus and Gonyaulax tamarensis. J. Plankton Res. 9: 459-482

Lapointe, B. E., Tenore, K. R., Dawes, C. J. (1984). Interactions between light and temperature on the physiological ecology of Gracilaria tikvahiae (Gigartinales: Rhodophyta). I. Growth, photosynthesis and respiration. Mar. Biol. 80: $161-170$

Madsen, D. M. (1991). Resource allocation at the individual plant level. Aquat. Bot. 41:67-86

Markager, S. (1993). Light absorption and quantum yield for growth in five species of marine macroalgae. J. Phycol. 29: $54-63$

Marsh, J. A., Dennison, W. C., Alberte, R. S. (1986). Effects of temperature on photosynthesis and respiration in eelgrass (Zostera marina L.). J. exp. mar. Biol. Ecol. 101: 257-267

McRoy, C. P. (1969). Eelgrass under Arctic winter ice. Nature 224: $818-819$

Nielsen, S. L., Borum, J., Geertz-Hansen, O., Sand-Jensen, K. (1989). Marine bundplanters dybdegrænse. Afhængighed af fysisk-kemiske faktorer og fytoplanktonbiomasse. Vand og Milje 5. 217-220

Orth, R. J., Moore, K. A. (1986). Seasonal and year-to-year variations in the growth of Zostera marina L. (eelgrass) in the lower Chesapeake Bay. Aquat. Bot. 24: 335-341

Perez, M., Romero, J., Duarte, C. M., Sand-Jensen, K. (1991). Phosphorus limitation of Cymodocea nodosa growth. Mar. Biol. 109: 129-133

Prézelin, B. B., Sweeney, B. M. (1978). Photoadaption of photosynthesis in Gonyaulax polyedra. Mar. Biol. 48: 27-35 
Sand-Jensen, K. (1975). Biomass, net production and growth dynamics in an eelgrass (Zostera marina L.) population in Vellerup Vig, Denmark. Ophelia 14: 185-201

Sand-Jensen, K. (1988). Mininum light requirements for growth in Ulva lactuca. Mar. Ecol. Prog. Ser. 50: 187-193

Sand-Jensen, K., Madsen, T. V. (1991). Minimum light requirements of submerged freshwater macrophytes in laboratory growth experiments. J. Ecol. 79: 749-764

Spence, D. H. N., Campbell, R. M. Chrystal, J. (1973) Specific leaf areas and zonation of freshwater macrophytes. J. Ecol. 61. 317-328

This article was submitted by G.W. Thayer, Beaufort, N. Carolina, USA
Sondergaard, M., Bonde, G. (1988). Photosynthetic characteristics and pigment content and composition in Littorella uniflora (L.) Aschers. in a depth gradient. Aquat. Bot. 32 $307-319$

Wium-Andersen, S., Borum, J. (1984). Biomass variation and autotrophic production of an epiphyte-macrophyte community in a coastal Danish area: I. Eelgrass (Zostera marina L.) biomass and net production. Ophelia 23: 33-46

Zimmerman, R. C., Smith, R. D., Alberte, R. S. (1989). Thermal acclimation and whole-plant carbon balance in Zostera marina L. (eelgrass). J. exp. mar Biol. Ecol. 130: 93-109

Manuscript first received: August 8, 1992

Revised version accepted: January 11, 1993 